\title{
Leaf-to-Whole Plant Spread Bioassay for Pepper and Ralstonia solanacearum Interaction Determines Inheritance of Resistance to Bacterial Wilt for Further Breeding
}

\author{
Ji-Su Kwon ${ }^{1}$, Jae-Young Nam ${ }^{2}$, Seon-In Yeom ${ }^{1,2, * \mathbb{D}}$ and Won-Hee Kang ${ }^{2, * \mathbb{C}}$ \\ 1 Department of Horticulture, Division of Applied Life Science (BK21 Four), Gyeongsang National University, \\ Jinju 52828, Korea; jskwon422@gnu.ac.kr \\ 2 Institute of Agriculture \& Life Science, Gyeongsang National University, Jinju 52828, Korea; \\ jynam812@gmail.com \\ * Correspondence: sunin78@gnu.ac.kr (S.-I.Y.); wh81kang@gmail.com (W.-H.K.)
}

check for

updates

Citation: Kwon, J.-S.; Nam, J.-Y.; Yeom, S.-I.; Kang, W.-H.

Leaf-to-Whole Plant Spread Bioassay for Pepper and Ralstonia solanacearum Interaction Determines Inheritance of Resistance to Bacterial Wilt for Further Breeding. Int. J. Mol. Sci. 2021, 22, 2279. https://doi.org/ 10.3390/ijms22052279

Academic Editor: Jan Schirawski

Received: 25 January 2021

Accepted: 23 February 2021

Published: 25 February 2021

Publisher's Note: MDPI stays neutral with regard to jurisdictional claims in published maps and institutional affiliations.

Copyright: (c) 2021 by the authors. Licensee MDPI, Basel, Switzerland. This article is an open access article distributed under the terms and conditions of the Creative Commons Attribution (CC BY) license (https:/ / creativecommons.org/licenses/by/ $4.0 /)$.

\begin{abstract}
Bacterial wilt (BW) disease from Ralstonia solanacearum is a serious disease and causes severe yield losses in chili peppers worldwide. Resistant cultivar breeding is the most effective in controlling BW. Thus, a simple and reliable evaluation method is required to assess disease severity and to investigate the inheritance of resistance for further breeding programs. Here, we developed a reliable leaf-to-whole plant spread bioassay for evaluating BW disease and then, using this, determined the inheritance of resistance to $R$. solanacearum in peppers. Capsicum annuum 'MC4' displayed a completely resistant response with fewer disease symptoms, a low level of bacterial cell growth, and significant up-regulations of defense genes in infected leaves compared to those in susceptible 'Subicho'. We also observed the spreading of wilt symptoms from the leaves to the whole susceptible plant, which denotes the normal BW wilt symptoms, similar to the drenching method. Through this, we optimized the evaluation method of the resistance to BW. Additionally, we performed genetic analysis for resistance inheritance. The parents, $F_{1}$ and $90 F_{2}$ progenies, were evaluated, and the two major complementary genes involved in the BW resistance trait were confirmed. These could provide an accurate evaluation to improve resistant pepper breeding efficiency against BW.
\end{abstract}

Keywords: Capsicum annuum; bacterial wilt; Ralstonia solanacearum; disease resistance; screening method; genetic inheritance analysis

\section{Introduction}

Chili pepper (Capsicum spp.) is an important economic crop that belongs to the Solanaceae family alongside potatoes, tomatoes, and eggplants. Pepper is widely consumed as fresh, dried, or processed products and provides many essential vitamins, and capsaicin is used as a major spicy source in most global cuisines [1]. The consumption of pepper has increased in the last 40 years, with production ranging from 9 to approximately 41 million tons and the cultivation area increasing from 2.4 to approximately 3.8 million ha [2]. The world trade value of hot peppers has consistently increased during the last decade, with the second-largest quantity after the tomato in Solanaceae crops [3]. Pepper production is continuously challenged by biotic stresses such as fungi, viruses, and bacteria [4]. Ralstonia solanacearum is the causal agent of bacterial wilt (BW), one of the most destructive soilborne bacterial pathogens in tropical and subtropical areas, with a wide host range of more than 400 plant species, especially the Solanaceae family including peppers [5]. BW by $R$. solanacearum is widely prevalent in peppers across much of Asia [6-8]. China accounted for approximately half of the world's production of peppers in 2017 (FAOSTAT), and the yield loss of BW from peppers is estimated to be approximately $20 \%-50 \%$ in its cultivation area [9].

$R$. solanacearum species is divided into five races according to host range and five biovar according to the utilization of disaccharides and hexose alcohols [10]. $R$. solanacearum 
is also classified based on geographical origin: phylotype I from Asia, phylotype II from America, phylotype III from Africa, and phylotype IV from Indonesia [11]. Recently, a few studies proposed to classify $R$. solanacearum into three species based on phylotype: R. psedosolanacearum (phylotype I and III), R. solanacearum (phylotype II), and R. syzygii (phylotype IV) $[12,13]$. Thus, the $R$. solanacearum species complex includes phenotypically diverse and heterogeneous strains causing $\mathrm{BW}$ in a variable host range. This is one of the constraint factors of resistance studies on $R$. solanacearum. The pathogen can invade the plant through root wounds and subsequently resides in the xylem vessels to block water transport and ultimately kills the plant host $[8,14]$.

Most studies on resistance to $R$. solanacearum in plants used two screening methods of R. solanacearum, i.e., root cut (soil)-drench and root-dipping inoculation [15-18]. However, both methods are difficult to determine the resistance degree according to the size of artificial root wounds, which leads to a large standard deviation due to low uniformity after inoculation [17]. The stem-puncture inoculation method also has limitations as it is difficult to apply this approach depending on the crop [19]. The leaf-inoculation method by syringe is a commonly used method for bacteria inoculation. In tobacco, the leaf inoculation method to $R$. solanacearum was already optimized and has been reported in several studies [20,21]. But this has not yet been reported to optimize a reliable bioassay in the resistance screening to $R$. solanacearum studies in peppers. This assay can infiltrate a relatively equal quantity of $R$. solanacearum into infected leaves and evaluate the quantification of pathogen growth in a plant. Additionally, leaf infiltration can recognize the inoculated leaves and non-inoculated systemic organs and establish disease scoring according to disease transmission in the whole plant.

To date, developed management programs of $R$. solanacearum are not sufficiently effective because chemical and biological controls are limited and ineffective in preventing the spread of $R$. solanacearum to the host plant [22,23]. One of the most effective BW control methods is the development of a resistance cultivar in the crops. Presently, several resistance sources of BW resistance have been evaluated to develop resistant cultivars in Capsicum spp. Several pepper accessions were reported among them, C. annuum 'MC4', C. annuum 'MC5', C. annuum 'LS2341', C. annuum 'PBC473', C. annuum 'PBC 1347', and C. annuum ' $\mathrm{PBC} 631^{\prime}$ are well known as the most strong BW resistant cultivars in various pathogens [24-26]. BW resistance is generally quantitatively inherited and is controlled by at least two genes in the pepper cultivar C. annuum 'Mie-Midori' [27]. Additionally, a pepper line C. annuиm 'PM687' reported additive effects with two to five genes to control the BW resistance [28]. The pepper line C. annuum 'LS2341' is reportedly polygenic and linked to a major quantitative trait loci (QTL) named Bw1 on chromosome 1 [29]. Recently, a major QTL named $q R R s-10.1$ in chromosome 10 was revealed as a resistance pepper line C. annuum 'BVRC1' [30].

Among them, C. annuum 'MC4' is a well-known accession with a strong level of resistance to various $R$. solanacearum strains $[15,24,31,32]$. However, despite reports of $C$. annuит ' $\mathrm{MC4}$ ' resistance to $\mathrm{BW}$, genetic inheritance analysis of BW resistance in C. annuиm 'MC4' has not been determined yet because of pathogen strain complexity and a lack of an efficient bioassay of $R$. solanacearum in peppers. Here, we developed a fast and reliable bioassay for phenotype evaluation against $R$. solanacearum in pepper germplasms. Using this method, BW resistance and susceptible symptoms were distinctly confirmed, and we successfully detected disease symptoms through whole plant wilting and validation for pepper cultivars. Through this, a genetic inheritance analysis of BW resistance was investigated in the parents, $\mathrm{F}_{1}$ and $\mathrm{F}_{2}$ progeny populations. The $\mathrm{BW}$ resistance trait in 'MC4' confirmed to be affected with at least two major complementary genes.

\section{Results}

\subsection{Identification of Leaf Wilt Symptoms between Resistant and Susceptible Pepper}

To identify the response of pepper plants on leaf wilting by $R$. solanacearum, we performed an infiltration of $R$. solanacearum SL1931 (hereafter SL1931) with $10^{6} \mathrm{CFU} / \mathrm{mL}$ in 
resistant 'MC4' and susceptible 'Subicho' to BW. We observed phenotypes of the infiltrated area for both cultivars from day 1 to day 4 after inoculation. Disease symptoms, leaf wilting, and yellowing with necrosis were observed in 'Subicho' at 3 days after inoculation (dai), whereas ' $\mathrm{MC} 4$ ' displayed less disease symptoms within 4 dai (Figure 1A). To confirm the resistant response between 'MC4' and 'Subicho', we quantified the level of bacterial cell growth in both cultivars. The differences in bacterial growth were observed at 2 dai but were significant from 3 to 5 dai, displaying 10 to 100 times more bacterial growth in 'Subicho' than in 'MC4' (Figure 1B).

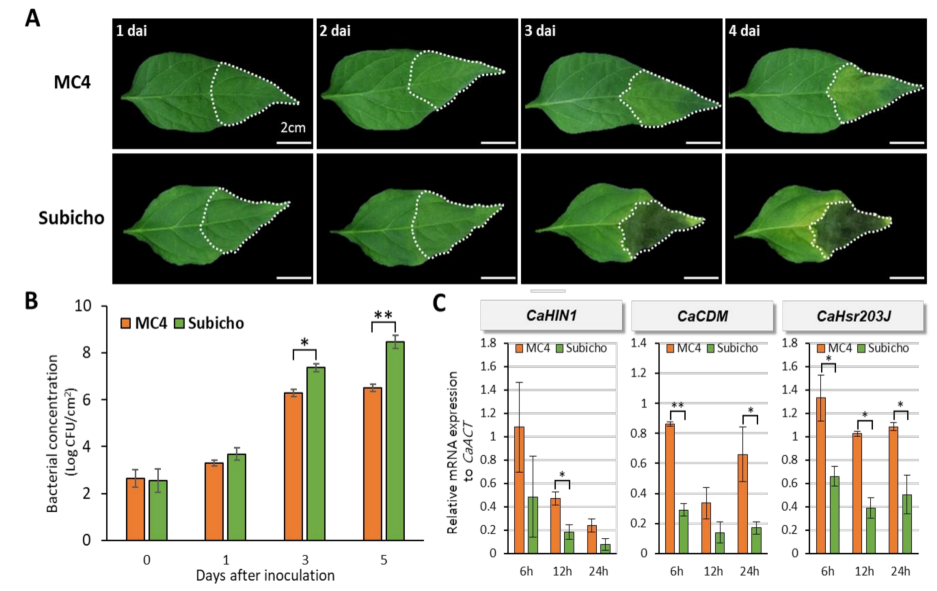

Figure 1. Assessment of bacterial wilt (BW) response by R. solanacearum in pepper leaves. The eightleaf stage seedlings were inoculated with $R$. solanacearum SL1931 by leaf infiltration with bacterial suspensions $1 \times 10^{6} \mathrm{CFU} / \mathrm{mL}$ to give inoculum volume of $0.1 \mathrm{~mL}$ per leaf. The plants were incubated in a growth room at $28^{\circ} \mathrm{C}$ with 16-h light a day. (A) Difference of necrotic lesions present in the leaf of inoculated 'MC4' and 'Subicho'. The symptom of 'MC4' (R) and 'Subicho' (S) leaf according to 1, 2, 3 , and 4 days after inoculation (dai) is shown. (B) Bacterial multiplication in the 'MC4' and 'Subicho' leaves. Bacterial suspension is $1 \times 10^{4} \mathrm{CFU} / \mathrm{mL}$ to give inoculum volume of $0.1 \mathrm{~mL} /$ leaf. Total of six to eight leaves used one experiment. Each vertical bar represents the S.E from two independent experiment. (C) Reverse-transcription polymerase chain reaction of defense-related expression gene levels in 'MC4' and 'Subicho' against $R$. solanacearum. The values represent the difference of relative expression in 'MC4' (R), 'Subicho' (S) leaves at $6 \mathrm{~h}, 12 \mathrm{~h}$, and $24 \mathrm{~h}$ after inoculation. Asterisks indicate statistically significant differences according to Student's $t$-test $\left({ }^{*} p<0.05,{ }^{* *} p<0.01\right)$.

Although no differences were observed during infection until 3 dai, the resistant response of $R$. solanacearum-inoculated leaves changed dramatically within a day between the two pepper cultivars (Figure 1C). We measured the transcript expression of defenserelated genes, $\mathrm{CaHIN1}, \mathrm{CaCDM}$, and $\mathrm{CaHsr} 203 \mathrm{~J}$, which were expressed during the resistant response related by various pathogens [33-35]. The expression level of the CaHIN1 gene was significantly increased in 'MC4' than in 'Subicho' at $12 \mathrm{~h}$ after inoculation (hai), and the $\mathrm{CaCDM}$ gene was also significant at 6 and 24 hai. We confirmed the transcript expression levels of the CaHsr203J gene was significantly increased in 'MC4' than in 'Subicho' at all three-time points (Figure 1C). Additionally, we conducted quantitative RT-PCR with other defense-related genes including PR4, PR10, and $\mathrm{CaAccOX}$ [36]. The expression levels of these genes in 'MC4' were significantly higher than those in 'Subicho' (Supplementary Figure S1), which are similar to the result as shown in Figure 1C. Collectively, these data strongly indicated that 'MC4' also has a suitable resistance to leaf wilting disease by $R$. solaneacerum alongside BW disease through root infection [15].

\subsection{BW Symptoms by R. solanacearum through Leaf-to-Whole Plant Spread Bioassay (LWB)}

To further understand the spectrum of defense responses to BW disease, the difference in phenotype of whole plants after leaf infection in the two cultivars was observed during 15 dai (Figure 2). 'Subicho' started to display wilt disease symptoms with the injected 
leaf abscising at 5 dai, whereas no differences in ' $\mathrm{MC} 4$ ' were observed until 10 dai. On the 15 dai, 'MC4' had a symptom of shedding and/or yellowing only with the inoculated leaves, while 'Subicho' had wilted and the whole plant died, which is a common BW disease symptom (Figure 2A,B). We confirmed the same wilt symptoms as the soil (root)-drenching inoculation method, although the leaf infection was conducted. We also represent the wilting rate (\%) data that analyzed two replicate experiments using 30 plants for each cultivar (Figure 2C). With consistency, 'Subicho' started to wither 6 dai, and rapid wilting progressed until 10 dai, and almost all the plants died on the 15 dai. Conversely, the 'MC4' was healthy with no wilting symptoms until two weeks after inoculation. Collectively, through the LWB, we could demonstrate quantified resistance and susceptible phenotypes to BW disease (Figure 2C).
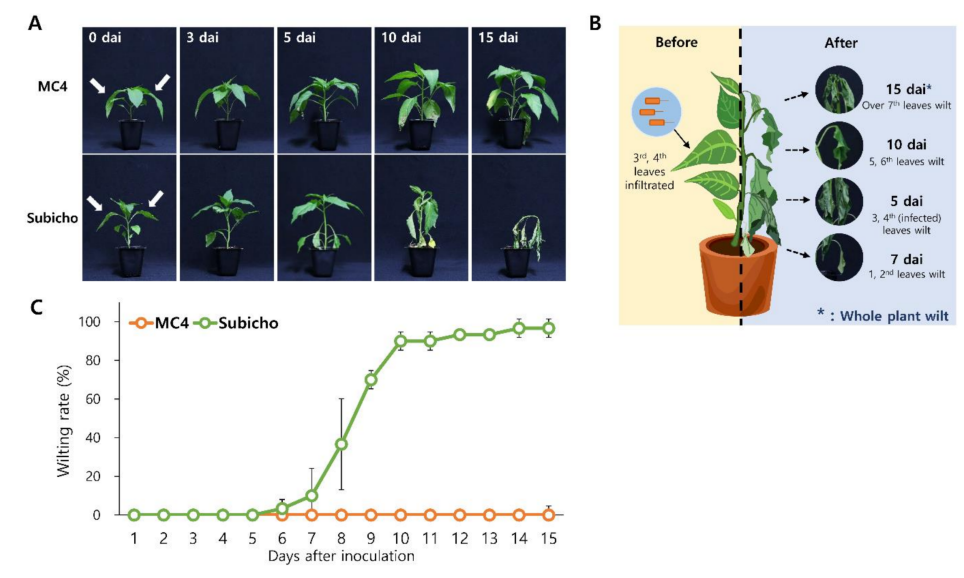

Figure 2. The difference in disease symptoms of leaf to whole plant spread bioassay (LWB) in pepper. Three weeks after transplanting, the eight-leaf stage seedlings were inoculated with $R$. solanacearum SL1931 by leaf infiltration with bacterial suspensions $1 \times 10^{6} \mathrm{CFU} / \mathrm{mL}$ to give inoculum volume of $0.1 \mathrm{~mL} /$ leaf. The plants were incubated in a growth room at $28^{\circ} \mathrm{C}$ with 16 -h light a day. (A) Difference of bacterial wilt (BW) symptom progression in inoculated 'MC4' and 'Subicho'. The phenotype of 'MC4' (R), 'Subicho' (S) according to $0,3,5,10$, and 15 days after inoculation (dai) is shown. (B) Illustration of a procedure in which the whole plant withers after leaf-infiltration. (C) Progress degree of wilt disease on 'MC4' and 'Subicho'. Disease severity of the plants was investigated every day after leaf inoculation. Green and Orange lines indicate 'Subicho' and 'MC4'. In total, 30 plants were analyzed for each cultivar. The arrows show inoculated leaves. Each data point represents the mean disease index for two independent experiment.

\subsection{Development of an Efficient Evaluation System for Resistance to R. solanacearum in Pepper}

A clear score criterion for resistant evaluation was established on the disease severity index (DSI) from 0 to 4 using LWB, which demonstrated identical BW symptoms with other methods (Figure 3A-E) [30,37]. Additionally, we measured closely examine the abscission of leaves in the stem after wilting (Figure $3 \mathrm{~F}-\mathrm{H}$ ). A score of one of the DSI represents the 3rd and 4th leaf abscission that is injected leaves simultaneously, the wilt of 2 leaves stands for $25 \%$ wilt symptoms ( 1 score of DSI) in total 8-leaf stage (Figure 3B,F). The DSI of 2 scores designated when three or/and four leaves wither or abscission, which is a symptom of $50 \%$ wilt in 8-leaf-stage (Figure 3C,G). The degree of more than half of the leaves wilted and a few alive is determined as DSI of 3 (Figure 3D,H). A plant with a DSI of $<2$ was considered resistant (R), $2 \leq$, a DSI of $<3$ was moderate resistance (MR), and susceptible (S) was defined as a DSI of $\geq 3$ in 15 dai based on Figure 2A,C results. 


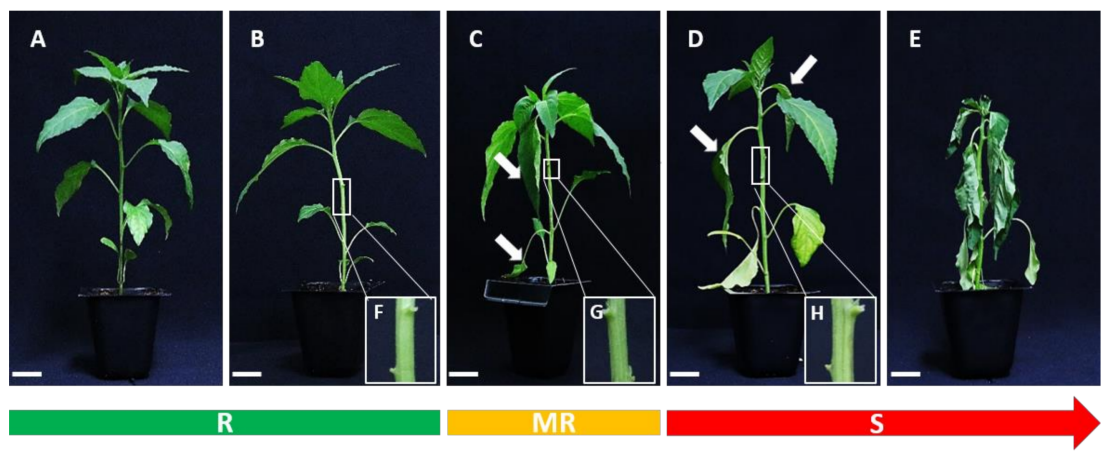

Figure 3. The disease symptoms scale ranging from 0 to 4 for BW evaluation. (A-E) Photographs representing 0 (no symptoms) to 4 (complete wilting) wilt symptoms stages. (F-H) The enlarged photographs of stem with abscission of leaves after $R$. solanacearum inoculation. The BW phenotype of three stages denoted resistance $(\mathrm{R})$ with a green bar, moderate resistance (MR) with a yellow bar, and susceptible (S) with a red bar. The white arrows indicate wilt and abscission leaves. The white under bar signifies $2 \mathrm{~cm}$.

Next, to ensure the optimal evaluation for BW resistance in peppers, we determined the optimal conditions of LWB. Among the environmental conditions, temperature most affects the vitality of $R$. solanacearum that inhabits tropical and subtropical areas. Appropriate temperature conditions $\left(28-32^{\circ} \mathrm{C}\right)$ of screening for bacterial wilt were identified in several studies on various crops and $R$. solanacearum strains $[17,38,39]$. We followed the above temperature and plant growth conditions and experimented to confirm the suitable inoculum concentration. Here, we compared four inoculum concentration levels from $10^{3} \mathrm{CFU} / \mathrm{mL}$ to $10^{6} \mathrm{CFU} / \mathrm{mL}$ at 10 -fold intervals (Figure 4). Differences in BW symptoms between the two cultivars can be verified at all concentrations of $10^{3} \mathrm{CFU} / \mathrm{mL}$ to $10^{6} \mathrm{CFU} / \mathrm{mL}$ according to statistical analysis. The DSI of $10^{3} \mathrm{CFU} / \mathrm{mL}$ concentration scored an average 2.6 in 20 dai, which does not represent a completely susceptible phenotype, and we considered it unsuitable. In the case of $10^{4} \mathrm{CFU} / \mathrm{mL}$, the disease progression was similar with $10^{3} \mathrm{CFU} / \mathrm{mL}$ until 11 dai, and after that disease progression was similar with $10^{5} \mathrm{CFU} / \mathrm{mL}$ from the 15 to 20 dai. The $10^{6} \mathrm{CFU} / \mathrm{mL}$ concentration was represented as the most suitable result. Resistance in 'MC4' maintained a DSI score of less than 1, whereas 'Subicho' displayed a fast-wilting symptom that scored a mean value of 3.8 until 20 dai (Figure 4). The $10^{6} \mathrm{CFU} / \mathrm{mL}$ concentration displayed relatively quick and clear phenotypic differences between resistant and susceptible cultivars than others at 10 dai, and the condition was maintained until 20 dai.

To further confirm and validate the LWB method, 12 commercial cultivars were reevaluated for resistance to $R$. solanacearum. The DSI of BW symptoms was checked daily according to LWB (Figure 5 and Table 1), which displayed R, MR, and S groups. We observed that 'PR-Daedeulbo' and 'Supermanidda' wilt in most individuals scored 3.3 and 3.9, respectively, of which 'Supermanidda' is as susceptible as 'Subicho' (Figure 5). 'Suppermanidda' started to wilt early at 4 dai, also its disease progression is similar to 'Subicho', an S-control cultivar. 'PR-Daedeulbo' was a MR phenotype until 14 dai, but then exceeded a score of 3 with over $70 \%$ of individuals dead and was thus identified as an $S$ cultivar. By contrast, 'PR-Jangwongeunje' and 'PR-Chengyang' belonged to the resistance category with the same DSI score of 1.8 in 20 dai but did not display the resistance of 'MC4' ( 0.6 score). The other 8 pepper accessions were denoted MR with scores between 2.0 to 2.5 , and a wilt rate (\%) at approximately half of the total tested plants for each (data not presented). Additionally, we conducted an experiment with another $R$. solancearum strain, HWA to 'MC4' and 'Subicho' using LWB. The HWA strain that is known as a highly strong pathogenic strain [16] showed similar disease symptoms and wilt rate (\%) with the SL1931 strain in 'MC4' and 'Subicho' (Supplementary Figure S2). These results indicate that LWB is a stable and reliable screening method for $R$. solanacearum in pepper. 


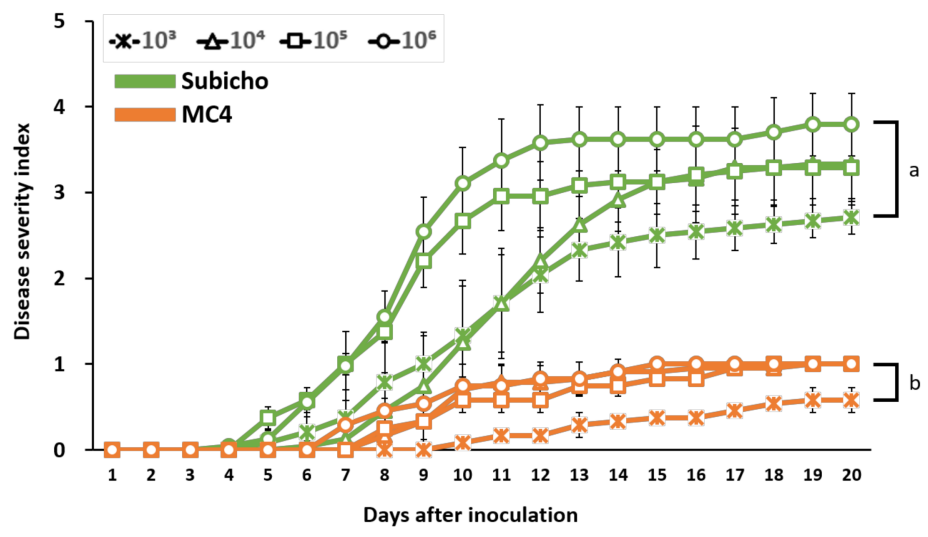

Figure 4. Occurrence of bacterial wilt on seedling of two pepper cultivars according to inoculum concentration. Three weeks after transplanting, the eight-leaf stage seedlings were inoculated with $R$. solanacearum SL1931 with bacterial suspensions $\left(1 \times 10^{3}, 1 \times 10^{4}, 1 \times 10^{5}\right.$, and $\left.1 \times 10^{6} \mathrm{CFU} / \mathrm{mL}\right)$ to give inoculum volume of $0.1 \mathrm{~mL} /$ leaf. Disease severity of the plants was investigated every day after inoculation. Green and orange lines indicate 'Subicho' and 'MC4', respectively. Each bar represents the S.E from three independent experiment with 24 plants. Values in the labeled with the same letter within each inoculum concentration are not significantly different in Duncan's multiple range test at $p=0.05$.

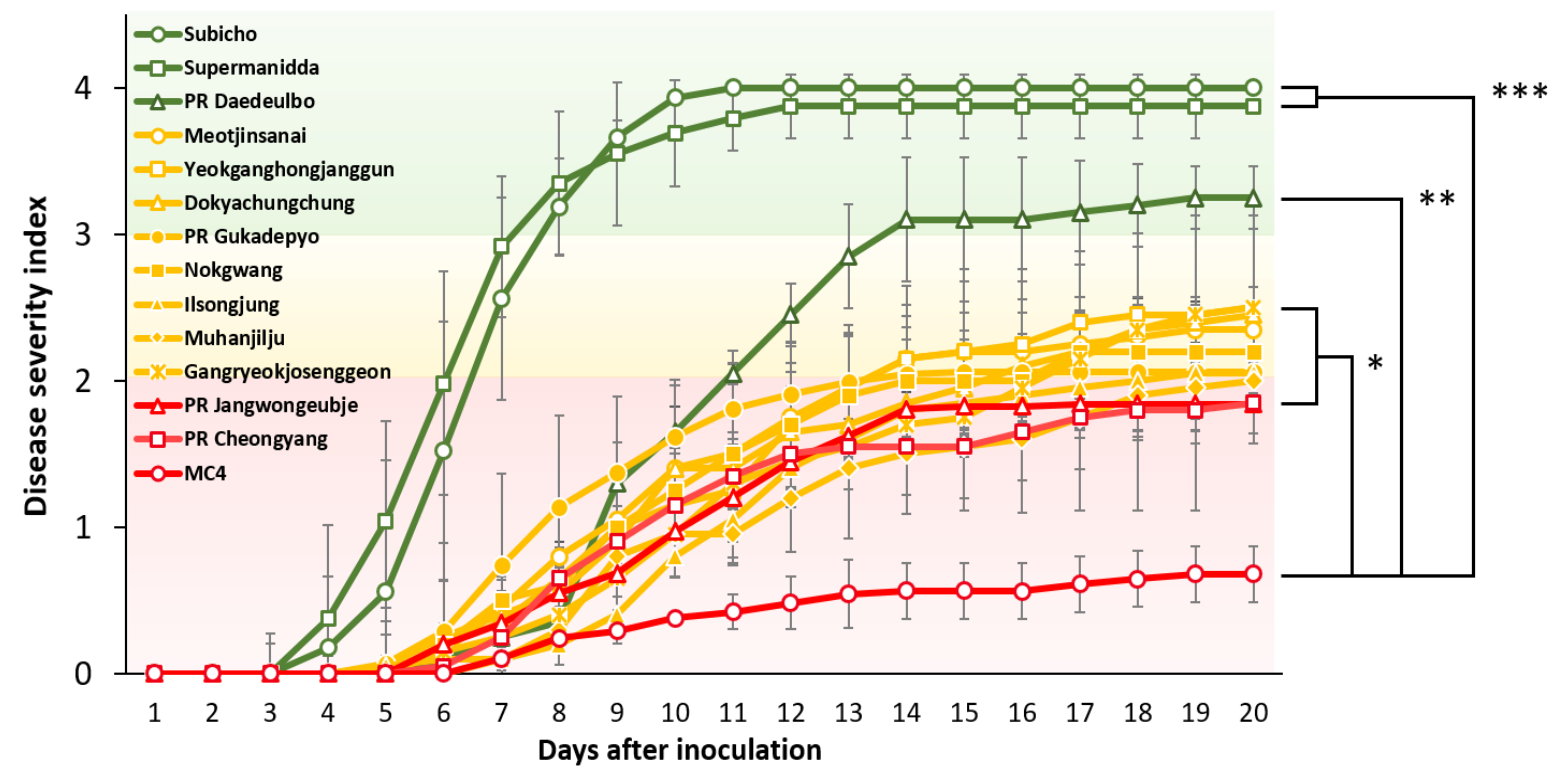

Figure 5. Disease progression through leaf to whole plant spread bioassay (LWB) in 12 pepper accessions. The eight-leaf stage seedlings were inoculated with $R$. solanacearum SL1931 with bacterial suspensions $1 \times 10^{6} \mathrm{CFU} / \mathrm{mL}$ to give inoculum volume of $0.1 \mathrm{~mL} /$ leaf. A line graph area of red, yellow, and green indicated resistance (R), moderate resistance (MR), susceptible (S), and the color of line was expressed the same as the areas based on the DSI score of the bacterial wilt on 20 dai for each cultivar. Each data point represents the mean disease index from at least two independent experiments. Each bar represents the S.E from three independent experiment with 24 plants. Asterisks indicate statistically significant differences $\left({ }^{*} p<0.05,{ }^{* *} p<0.01,{ }^{* * *} p<0.001\right)$ in AUDPC (0 to 15d), according to Student's $t$-test with 'MC4'. 
Table 1. BW phenotype of LWB in 12 commercial chili pepper cultivars to R. solanacearum.

\begin{tabular}{|c|c|c|c|c|c|c|c|c|}
\hline \multirow{3}{*}{ Cultivar } & \multicolumn{7}{|c|}{ In this Study (LWB) } & \multirow{3}{*}{$\begin{array}{c}\text { Previous Study } \\
\text { Root-Drench Phenotype e,f }^{\text {ef }}\end{array}$} \\
\hline & \multicolumn{4}{|c|}{ Days after Inoculation } & \multirow{2}{*}{ AUDPC $^{b}$} & \multirow{2}{*}{ rAUDPC $(\%)^{c}$} & \multirow{2}{*}{ Phenotype $^{\mathrm{d}}$} & \\
\hline & 0 & 7 & 10 & 15 & & & & \\
\hline Gangryeokjosenggeon & $0^{\mathrm{a}}$ & 0.3 & 1.0 & 1.8 & $9.4 \mathrm{bc} g$ & 24.1 & $\mathrm{R}$ & $\mathrm{R}^{\mathrm{e}}$ \\
\hline PR Cheongyang & 0 & 0.3 & 1.2 & 1.6 & $9.7 \mathrm{bc}$ & 24.9 & $\mathrm{R}$ & $\mathrm{MR}^{\mathrm{e}}$ \\
\hline Ilsongjung & 0 & 0.1 & 0.8 & 1.9 & $8.3 \mathrm{c}$ & 21.3 & $\mathrm{R}$ & $\mathrm{MR}^{\mathrm{e}}$ \\
\hline PR Jangwongeubje & 0 & 0.3 & 1.0 & 1.8 & $10.2 \mathrm{bc}$ & 26.0 & $\mathrm{R}$ & $S^{e}$ \\
\hline Muhanjilju & 0 & 0.1 & 1.0 & 1.6 & $8.2 \mathrm{c}$ & 20.9 & $\mathrm{R}$ & $\mathrm{S}^{\mathrm{e}, \mathrm{f}} / \mathrm{MR}^{\mathrm{f}} / \mathrm{R}^{\mathrm{f}}$ \\
\hline Dokyachungchung & 0 & 0.4 & 1.4 & 2.0 & $12.5 \mathrm{bc}$ & 32.0 & MR & $\mathrm{R}^{\mathrm{e}}$ \\
\hline Meotjinsanai & 0 & 0.5 & 1.4 & 2.2 & $13.4 \mathrm{bc}$ & 34.2 & MR & $\mathrm{MR}^{\mathrm{f}} / \mathrm{R}^{\mathrm{f}}$ \\
\hline Nokgwang & 0 & 0.5 & 1.3 & 2.0 & $12.5 \mathrm{bc}$ & 32.0 & MR & - \\
\hline PR Gukgadeapyo & 0 & 0.7 & 1.6 & 2.1 & $15.3 \mathrm{~b}$ & 39.3 & MR & $\mathrm{S}^{\mathrm{e}}$ \\
\hline Yeokganghongjanggun & 0 & 0.4 & 1.2 & 2.3 & $12.0 \mathrm{bc}$ & 30.4 & MR & $\mathrm{S}^{\mathrm{e}}$ \\
\hline PR Daedeulbo & 0 & 0.3 & 1.7 & 3.1 & $15.6 \mathrm{~b}$ & 40.0 & $S$ & $\mathrm{~S}^{\mathrm{e}}$ \\
\hline Supermanidda & 0 & 2.9 & 3.7 & 3.9 & $39.0 \mathrm{a}$ & 100 & $S$ & $\mathrm{~S}^{\mathrm{e}}$ \\
\hline 'MC4' & 0 & 0.1 & 0.4 & 0.6 & $3.5 \mathrm{~d}$ & 8.9 & $\mathrm{R}$ & $\mathrm{R}^{\mathrm{e}}$ \\
\hline 'Subicho' & 0 & 2.6 & 3.9 & 4.0 & $38.5 \mathrm{a}$ & 98.7 & $S$ & $\mathrm{~S}^{\mathrm{e}}$ \\
\hline
\end{tabular}

${ }^{a}$ Disease severity index (DSI) was represented by a 0 to 4 rating scale. ${ }^{b}$ The AUDPC was calculated based on DSI scores evaluated at $0,7,10$, and 15 days after inoculation (dai). ' Relative (r) AUDPC (\%) of each cultivar to AUDPC of the 'Suppermanidda' that is most the susceptible cultivar. ${ }^{\mathrm{d}}$ DSI of $<2$ is considered resistant, $2 \leq$ DSI $<3$ is moderately resistant and susceptible was defined with DSI of $\geq 3$. Each data point represents the mean DSI from three independent experiments. A total of 30 plants were analyzed for each cultivar. ${ }^{\mathrm{e}}$ Root-cut drench method by Hwang et al. (2017). ${ }^{\mathrm{f}}$ Root-dipping method by Lee et al. (2018). ${ }^{\mathrm{g}}$ Each value represents the mean disease index of values in the labeled with the same letter with each column are not significantly different in Duncan's multiple range test at $p<0.05$.

Furthermore, on the LWB method, we compared the BW phenotype with the previous root and soil inoculation methods (Table 1). We also calculated the area under the disease progress curve (AUDPC) and relative (r) AUDPC based on DSI scores at 7, 10, and 15 dai. Not only the DSI for wilting evaluation, but also the rAUDPC (\%) value was able to distinguish between $0 \%-30 \%$ R, 30\%-40\% MR, and $40 \%-100 \%$ as $S$ in 15 dai [15]. The AUDPC and rAUDPC (\%) were distributed as 3.5\% and $8.9 \%$ in 'MC4', and 'Subicho' was $38.5 \%$ and $100 \%$, displaying significant results as controls. Of the 12 commercial pepper cultivars, the rAUDPC (\%) of 'Supermanidda' (100\%) and 'Muhanjilju' (20.9\%) had greater results for BW susceptibility and resistance, respectively. We compared the traits with the other inoculation methods and analyzed the DSI score of the BW phenotype 15 dai when 'Subicho' was in a saturating state. The 'Gangryeokjosenggeon' (R), 'Meotjinsanai' (MR), 'PR-Daedeulbo' (S), and 'Supermanidda' (S) have the same traits in either inoculation method (Table 1). However, the traits of the root-drenching method in 'PR-Cheongyang', 'Ilsongjung', 'Muhanjilju', and PR-'Jangwongeubje' were MR or S phenotypes [15], but in this study represented all $\mathrm{R}$ phenotypes. 'Muhanjilju' and 'Meotjinsanai' also displayed previously different traits with $S, M R$, or $\mathrm{R}$ on infection methods and/or $R$. solanacearum strains [16], whereas we observed $\mathrm{R}$ and MR uniformly in each cultivar, respectively (Table 1 and Figure 5). Even though it could be difficult to determine the exact traits to BW, our results suggested that the LWB could be a simple and reliable evaluation method for BW resistant screening in peppers.

\subsection{Inheritance Analysis of Resistance to R. solanacearum in Pepper}

To analyze the inheritance of resistance to $R$. solanacearum in ' $M C 4$ ', the parents, $\mathrm{F}_{1}$ and $\mathrm{F}_{2}$, progenies were evaluated until the disease progressed at 30 dai (Table 2 and Table S2, Figure 6). The parents, 'MC4' and 'Subicho', maintained resistance and susceptibility, respectively. The wilting progression of $F_{1}$ plants was conspicuously slower than in the susceptible parent, and the wilt rates of $F_{1}$ until 20 dai were closer to the resistant parent. In generation $\mathrm{F}_{2}$, the individuals were distributed on most DSI scores, but resistant plants were most common both at 15 and 20 dai. However, these BW symptoms in parents, $\mathrm{F}_{1}$ and $\mathrm{F}_{2}$, developed continuously until the end of the experiment at 30 dai (Figure 6 and Table 2). These results suggested that BW resistance acts as a QTL with a few genes in 'MC4'. 
Table 2. Disease evaluation design and the number of plants to parents and their progenies based on disease severity index in 20 dai against $R$. solanacearum SL1931 strain.

\begin{tabular}{|c|c|c|c|c|c|c|c|c|c|}
\hline \multirow{2}{*}{ Population $^{\text {a }}$} & \multirow{2}{*}{ No. of Plants } & \multicolumn{5}{|c|}{ Disease Severity Index } & \multirow{2}{*}{ Mean of DSI ${ }^{b}$} & \multirow{2}{*}{ Wilt Rate $(\%)^{c}$} & \multirow{2}{*}{ AUDPC $^{\mathrm{d}}$} \\
\hline & & 0 & 1 & 2 & 3 & 4 & & & \\
\hline MC4 & 30 & 6 & 24 & 0 & 0 & 0 & 0.8 & 0 & 7.5 \\
\hline Subicho & 30 & 0 & 0 & 0 & 0 & 30 & 4.0 & 100 & 50.3 \\
\hline $\mathrm{F}_{1}$ & 30 & 0 & 12 & 4 & 0 & 14 & 2.5 & 46.7 & 22.7 \\
\hline $\mathrm{F}_{2}$ & 90 & 0 & 44 & 11 & 1 & 34 & 2.3 & 38.8 & 21.9 \\
\hline
\end{tabular}

a 'MC4' and 'Subicho' is resistance (R) and susceptible (S) parent line, respectively. The $\mathrm{F}_{1}$ population crossed 'Subicho' (S) x 'MC4' (R) and $F_{2}$ population derived from self-cross of $F_{1}$ plants. ${ }^{b}$ The disease severity index (DSI) was calculated at 15 days after inoculation based on a 0 to 4 rating scale. ${ }^{c}$ Wilting was defined as DSI at 20 dai of $\geq 3 .{ }^{\mathrm{d}}$ The area under the disease progress curve (AUDPC) was calculated from scores (0-4) evaluated at $0,7,10,15$, and 20 dai.

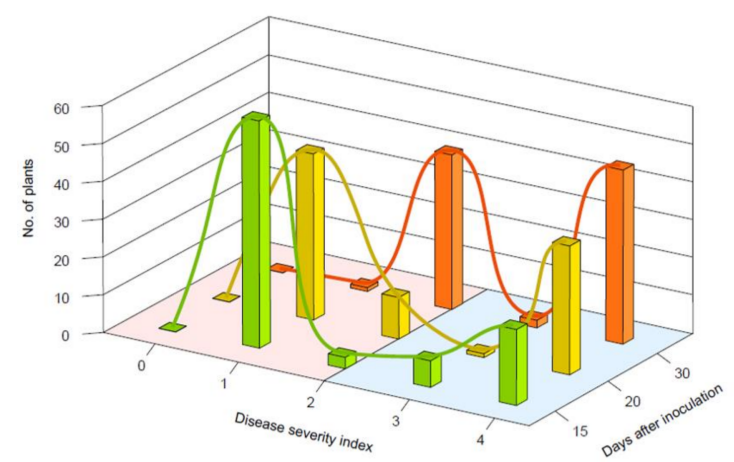

Figure 6. Histograms and curve graphs represented the number of plants' phenotype segregation based on disease severity scores of the $F_{2}$ population $(n=90)$ at 15 (green bar), 20 (yellow bar), and 30 dai (orange bar). The plants were inoculated with $R$. solanacearum strain SL1931, the bacterial suspensions are $1 \times 10^{6} \mathrm{CFU} / \mathrm{mL}$ to give inoculum volume of $0.1 \mathrm{~mL} /$ leaf at fully expended 3rd and 4 th leaf stages in a plant. The red zone and blue zone represent resistance and susceptible, respectively.

We measured the segregation ratio of BW resistance with the chi-square analysis in the $\mathrm{F}_{2}$ population with disease progression. At 15 dai, segregation in $\mathrm{F}_{2}$ yielded 63 resistant and 27 susceptible plants that fitted closely to a 11:5 $(p>0.5)$ and $3: 1$ ratio $(p>0.1)$. It appeared more closely at an 11:5 ratio than 3:1, which demonstrated that BW resistance was predominantly controlled by at least one major factor and/or two major alleles around two weeks after inoculation. At 20 dai, resistant plants in the $\mathrm{F}_{2}$ prevailed with 61 resistant plants versus 29 susceptible, which nearly matched a 9:7 ratio $(p>0.5)$ and 11:5 ratio $(p>0.1)$. Lastly, the segregation was represented as a 9:7 ratio $(p>0.05)$ with 42 resistant plants versus 48 susceptible at 30 dai (Figure 6 and Table 3). According to these chisquare tests, there were significant differences in the segregation ration during pepper- $R$. solanacearum interaction. The BW resistance in ' $\mathrm{MC} 4$ ' may be affected by a major dominant factor until 15 dai alongside at least two factors controlling the resistance after the 20 dai. Additionally, the separation ratios of 11:5 and 9:7 were consistently represented with a high $p$-value closest at 20 and 30 dai, which indicated that two complementary dominant genes could mainly control the resistance to BW in ' $\mathrm{MC4}$ '. 
Table 3. Segregation of $R$. solanacearum SL1931 resistance in $F_{2}$ population at 15, 20, and 30 dai.

\begin{tabular}{cccccccccccc}
\hline DAI & $\mathbf{3 : 1}$ & $\mathbf{9 : 7}$ & $\mathbf{1 5 : 1}$ & $\mathbf{3 : 1 3}$ & $\mathbf{1 1 : 5}$ & $\mathbf{9 : 6 : 1}$ & $\mathbf{1 2 : 3 : 1}$ & $\mathbf{9 : 3 : 4}$ & $\mathbf{7 : 6 : 3}$ & $\mathbf{9 : 3 : 3 : 1}$ & $\mathbf{3 : 6 : 3 : 4}$ \\
\hline 15 & $1.2^{* *}$ & 6.9 & 86.6 & 155.2 & $0.1^{* * *}$ & 111.0 & 93.47 & 14.0 & 44.90 & 55.7 & 144.3 \\
20 & 9.3 & $0.9^{* * *}$ & 163.6 & 106.0 & $2.4^{* *}$ & 169.6 & 163.6 & 9.9 & 35.4 & 161.0 & 79.8 \\
30 & 38.5 & $3.4^{*}$ & 340.5 & 46.0 & 20.4 & 383.2 & 386.8 & 79.6 & 110.1 & 208.7 & 51.1 \\
\hline
\end{tabular}

$p$ value indicate according to ${ }^{*} p>0.05,{ }^{* *} p>0.1,{ }^{* * *} p>0.5$.

\section{Discussion}

As global warming continues, the damage of BW is spreading beyond tropical and subtropical regions worldwide. The interaction between $R$. solanacearum and its plant hosts has been studied as plant resistance to bacterial phytopathogens for more than two decades [22,40,41]. To study various interactions with plants, it is important to establish accurate screening. Accordingly, the inoculation method that makes good use of the infection characteristic of the bacteria was dominated since $R$. solanacearum is a soil-dwelling bacterium. Soil-drench or/and root-dipping inoculation is mostly used to investigate bacterial wilt disease progress on peppers, tomatoes, eggplants, potatoes, and the model plants Medicago and Arabidopsis [15,38,40,42-44]. Using this root-infection method requires a wound of the root; however, there is uncertainty regarding the infections before the symptoms alongside difficulty in knowing the exact resistance phenotype depending on the degree of artificial root wound. Consequentially, variation and deviation of the BW symptom appear large in plants [15-18]. To overcome these problems, we developed an LWB assay for BW on peppers.

In this study, we confirmed the different symptoms in leaves after inoculation to discover if the method is suitable for resistant 'MC4' and susceptible 'Subicho'. Additionally, the transcript levels of defense-related genes and bacterial cell growth were significantly different in the resistant or susceptible cultivars following R. solanacearum infection. Although the strains and cultivars were different from our study, the result was consistent with the real-time visualization of the bioluminescent $R$. solanacearum strain BL-Rs7 colonization of grafted peppers in Du et al. (2019) that demonstrated more aggregation of the pathogen in susceptible cultivar (BVRC 1) then resistance (BVRC 25) [30]. Likewise, in our study, 'MC4' inhibited the proliferation of $R$. solanacearum and displayed a higher expression level of cell-death related genes compared with 'Subicho'. The cell-death markers used in this study were related to the resistant response and defense-related pathway [34,45]. As a result, it can be assumed that the resistance-related factor acts for the defense as 'MC4' has a higher expression value than that of 'Subicho'. Through these results, we confirmed that 'MC4' was a clear BW resistance cultivar compared with 'Subicho'. According to the study of Akinori et al. (2007), the same BW phenotype was also represented in tobacco when leaf-infiltration and root-inoculation were performed, similar to our studies [20]. The leafinfiltration method is more useful to elucidate molecular events than root (soil)-drenching to better understand the interaction between plants and pathogens since it is possible to inoculate equally $[20,21,46]$. In conclusion, the wilting symptoms appeared on the whole plant even when inoculated to the leaves, which confirmed the same symptoms as the root infection.

The temperature was the main environmental factor in which $R$. solanacearum affects crops $[47,48]$. An experiment was conducted to confirm the most suitable temperature conditions for LWB before the inoculum concentration experiment. As a result of our experiments at 25,28 , and $32{ }^{\circ} \mathrm{C}$, two suitable temperatures were revealed except for $25^{\circ} \mathrm{C}$ (data not shown). Additionally, the studies derived that the temperature of $25^{\circ} \mathrm{C}$ was not suitable for peppers and tomatoes, respectively, in the screening research for optimization condition $[15,38]$. Therefore, the temperature was fixed at $28-30{ }^{\circ} \mathrm{C}$ in the experimental conditions, and the inoculum concentrations were tested to identify the most suitable for the LWB. The most appropriate concentration was $10^{6} \mathrm{CFU} / \mathrm{mL}$ indicating that it was 
sufficiently able to confirm the phenotypic difference between two control cultivars with a lower concentration and less volume than the drenching method.

We executed the LWB in eleven commercial pepper cultivars with BW phenotype information and one commercial pepper cultivar with no information. As a result, five and two cultivars represented R-phenotype and S-phenotype, respectively, and the others were the MR-phenotype. Among them, the cultivars of 'Muhanjilju', 'PR-Jangwongeubje', and 'PR-Gukgadeapyo' demonstrated susceptibility in Hwang et al. (2017), but our results demonstrated the resistance of BW phenotypes, which is an opposite result. These results could affect the metabolic activity of the host due to artificial wounds in the root, making it difficult to identify the accurate BW phenotype. In case of 'Muhanjilju', it represented R, MR, or S-phenotypes according to inoculation with various $R$. solanacearum strains in Lee et al. (2018) [16]. Additionally, the 'Subicho' was inoculated by soil-drenching without root wounds and represented 0.7 DSI scores ( 0 to 4 scale scores) with very low disease incidence 15 dai [15], in which the BW phenotype is dependent on the root wound in pepper. For this reason, the study of interactions with pepper- $R$. solanacearum is exceptionally difficult. An accurate and reliable bioassay (LWB) can identify the exact BW phenotype in pepper through the equal inoculate without any wound of the root.

One of the most effective control managements is developing a resistance cultivar in the crops by integrating a resistance gene. Until now, a few sources of BW resistance have been reported in Capsicum spp. including C. annuum 'MC4', 'MC5', 'LS2341', and 'PBC631' [24-26]. In previous studies on the resource of resistance to BW, different QTL studies for only a few were determined that a major QTL ( $q R R s-10.1$ ) in 'BVRC1' accession and one major (Bw1) in 'LS2341' accession were identified at different chromosome 10 and 1 for each resource, respectively $[29,30]$. Despite the above reports of resistance to bacterial wilt, there are no useful cultivars comprised of high resistance with good yield and desirable agronomic traits. In this regard, understanding the genetic control for resistance to BW disease in plant breeding programs is essential and required to increase their efficiency, especially for planning a proper breeding method [49,50].

'MC4' is well-known to have high-level resistance to the species of the $R$. solanacearum complex $[24,26,31]$, but the genetic inheritance of 'MC4' for BW resistance has not been identified yet. In this study, we constructed the $\mathrm{F}_{2}$ population with 'Subicho' (susceptible) and performed an analysis of the inheritance of BW resistance through the LWB. We identified BW resistance as dominant and over susceptible, and at least two pairs of genes appeared to control the trait in a complementary manner. Matsunaga et al. (1998) studied the mode of inheritance of BW resistance by crossing the resistant sweet pepper cultivar 'Mie-Midori' with the susceptible 'AC2258' and found that bacterial wilt resistance demonstrated incomplete dominance, and at least two genes were involved in resistance [27]. This result is similar to our segregation ratio date representing two major genes affected in the BW resistance of 'MC4' in this study. Additionally, Denis et al. (2005) concluded that two to five genes with additive effects were estimated to control the resistance. Tran et al. (2010) reported various dominance genetic effects as polygenic or oligogenic for $R$. solanacearum using six resistant pepper lines and five susceptible pepper lines [51]. Recently, Heshan et al. (2019) represented the disease index and wilt rate $(\%)$ using the $\mathrm{F}_{2}$ plants $(n=440)$, in which the wilting pattern of segregation was similar to our result [30]. Especially, the disease symptoms kept progressing over time alongside no represented complete dominance resistance like 'MC4' (R-parent). In the $\mathrm{F}_{1}$ and $\mathrm{F}_{2}$ generation, and which indicated to appear epistasis dominant like our result. These studies indicated that the inheritance of BW resistance is complicated, and a minimum of two genes interact to express resistance traits in the pepper germplasm. Our data suggest that the LWB method may determine a more exact BW resistance phenotype of pepper germplasms and reveal the interaction of plant-pathogens at the molecular level. Further investigations of inheritance factors could provide insights into QTL analysis and the development of BW resistance-related molecular markers. 


\section{Materials and Methods}

\subsection{Plant Materials and Growth Conditions}

Two varieties of peppers, Capsicum annuum 'MC4' with resistance to $R$. solanacearum and C. annuum 'Subicho' with susceptibility to R. solanacearum, were provided by Dr. SeonWoo Lee (Dong-A University, Korea). The 12 commercial pepper cultivars (5 resistant, 5 moderately resistant, and 2 susceptible cultivars; Table 1) were used. The 'MC4' was crossed with 'Subicho' to get $\mathrm{F}_{1}$ plants. The $\mathrm{F}_{2}$ population was obtained by self-pollination of $F_{1}$ plants. The pepper plants were kept in a growth chamber at $29 \pm 1{ }^{\circ} \mathrm{C}$ under a $16 \mathrm{~h}$ light $/ 8 \mathrm{~h}$ dark cycle with $50 \%$ humidity for $3-4$ weeks. We inoculated $R$. solanacearum onto the $3 \mathrm{rd}$ and 4 th leaves of fully expanded four-leaf-stage on pepper plants.

\subsection{Bacteria Inoculation and Quantification}

The strain R. solanacearum SL1931 (race1, phylotype I) was obtained from Dr. SeonWoo Lee (Dong-A University, Korea). Bacterial cells were streaked and grown on Kelman's tetrazolium chloride gar medium and maintained at $28^{\circ} \mathrm{C}$ for $48 \mathrm{~h}$. A single fluidal colony of $R$. solanacearum was grown on CPG broth and shaken at $250 \mathrm{rpm}$ at $28^{\circ} \mathrm{C}$ for $24 \mathrm{~h}$. A bacterial culture suspension was diluted with distilled water to adjust the concentration to $10^{8} \mathrm{CFU} / \mathrm{mL}\left(\mathrm{OD}_{600}=0.3\right)$ [15]. Ten-fold serial dilutions of bacteria from $10^{3} \mathrm{CFU} / \mathrm{mL}$ to $10^{6} \mathrm{CFU} / \mathrm{mL}$ per leaf were used for inoculation. Seedlings of fully expanded four-leaf-stage were inoculated with $0.1 \mathrm{~mL}$ bacteria/leaf using a needleless syringe. Disease symptoms were observed under controlled conditions of $29 \pm 1{ }^{\circ} \mathrm{C}$ under $16 \mathrm{~h}$ of light a day with $50 \%$ humidity for 20 days. The leaf-inoculation assay was performed with three independent tests, and each consisted of at least 8 plants per cultivar. Inoculum concentration was performed with $10^{6} \mathrm{CFU} / \mathrm{mL}$ per leaf for the inheritance analysis of the $\mathrm{F}_{2}$ population.

Bacterial quantification was performed like below with modification described by Yi et al. (2009) [52]. To determine in plant bacterial growth, pepper plants (C. annuum 'MC4' and 'Subicho') were leaf-inoculated with bacterial suspensions $\left(1 \times 10^{4} \mathrm{CFU} / \mathrm{mL}\right)$. Inoculated leaves were harvested at various time points for further analysis. Two independent assays were performed, which consisted of 6-8 samples for each time point in an experiment. Bacterial growth was measured by grinding inoculated samples in distilled water, plating serially diluted tissue samples with two replicates on CPG agar with $0.1 \%$ gentamicin $(v / v)$, and counting colony-forming units.

\subsection{Disease Evaluation and Data Analysis}

Disease evaluations were assessed daily after inoculation with $R$. solanacearum as described below. The disease severity index (DSI) of individual inoculated plants was rated on a scale of 0 to 4 as five phases in which 0 is no wilt disease symptoms observed; 1 is minor symptoms with less than $25 \%$ wilted leaves; 2 is moderate symptoms with $25 \%-50 \%$ wilted leaves; 3 is severe symptoms with $50 \%-75 \%$ wilted leaves; 4 is $75 \%-100 \%$ wilted leaves or dead plant. The area under the disease progress curve (AUDPC) was calculated during the disease observation (0 to 15 dai) with a DSI value. [53]. Wilting rate (\%) was calculated [The number of wilt plant/the number of total plants] x 100 . The differences between the mean values of disease scores of the pepper cultivars were analyzed using Duncan's multiple range tests, and $p<0.05$ was considered a significant difference. Statistical analysis used SAS (SAS 9.1, SAS Institute Inc., Cary, NC, USA).

\subsection{Quantitative RT-PCR of Defense-Related Genes}

Total RNA was extracted from pepper leaves inoculated with the pathogen using the Trizol reagent (Invitrogen, Carlsbad, USA), and 2 ug of total RNA were reverse transcribed using Superscript IV (Invitrogen, Carlsbad, USA). To confirm the plant response against $R$. solanacearum infection, quantitative RT-PCR was performed using the defense-related genes (Supplementary Table S1) [34,36,54]. The following cycling conditions were used: 1 cycle of $94{ }^{\circ} \mathrm{C}$ for $3 \mathrm{~min} ; 28$ cycles or 30 cycles of $95^{\circ} \mathrm{C}$ for $30 \mathrm{~s}, 58^{\circ} \mathrm{C}$ for $30 \mathrm{~s}$, and $72{ }^{\circ} \mathrm{C}$ for $30 \mathrm{~s}$; $72{ }^{\circ} \mathrm{C}$ for $5 \mathrm{~min}$. The actin gene (designated $\mathrm{CaACT}$ ) was used as an endogenous control 
to normalize the expression levels. Expression levels were reported as three replicates as mean values with standard errors.

\section{Conclusions}

Breeding a resistant cultivar is most effective in controlling bacterial wilt that causes serious yield losses in peppers worldwide. An accurate and reliable evaluation method is necessary to evaluate disease severity and reveal the genetic inheritance for BW resistance. We established a simple LWB to evaluate BW disease and then, using this, analyzed the inheritance of BW resistance through a 'Subicho' $\times$ ' $\mathrm{MC}^{\prime}{ }^{\prime} \mathrm{F}_{2}$ population. The BW resistance response of ' $\mathrm{MC4}$ ' represents lower disease symptoms in leaves than susceptible 'Subicho', and we observed the spreading of wilt symptoms from leaves to a whole susceptible plant, similar to the drenching method. As a result, we optimized the evaluation method of resistance to BW with 12 commercial pepper cultivars. Using LWB, we confirmed the two major complementary genes related to the $\mathrm{BW}$ resistance trait through the analyzed genetic inheritance in $90 \mathrm{~F}_{2}$ progenies. This bioassay could promote an accurate evaluation of BW disease phenotype, and the two inheritance factors of 'MC4' could provide useful information for further QTL analysis in pepper breeding.

Supplementary Materials: Supplementary materials can be found at https://www.mdpi.com/1422 $-0067 / 22 / 5 / 2279 / \mathrm{s} 1$.

Author Contributions: J.-S.K. performed the experiments, data analysis, and wrote the manuscript; J.Y.N. collected samples and data analysis; W.-H.K. and S.-I.Y. conceived and designed the experiments, organized and wrote the manuscript, and supervised the project. All authors have read and agreed to the published version of the manuscript.

Funding: This research was supported by the Basic Science Research Program through the National Research Foundation of Korea (NRF) funded by the Korean Government (NRF-2017R1E1A1A01072843, 2015R1A6A1A03031413 and 2019R1C1C1007472). J.-S.K. was supported by a scholarship from the BK21 four Program from the Ministry of Education.

Data Availability Statement: The data that support the findings of this study are available from the corresponding authors upon reasonable request.

Acknowledgments: We are grateful to Seon-Woo Lee (Dong-A University, Korea) for providing pepper seeds and bacterial strains.

Conflicts of Interest: The authors declare no conflict of interest.

\section{References}

1. Howard, L.R.; Wildman, R.E. Antioxidant vitamin and phytochemical content of fresh and processed pepper fruit (Capsicum annuum). In Handbook of Nutraceuticals and Functional Foods, 2nd ed.; CRC Press: Boca Raton, FL, USA, 2007; pp. 165-191.

2. Faostat. 2020. Available online: http:// www.fao.org (accessed on 22 October 2020).

3. Comtrade UN. UN Comtrade Database. Available online: http:// comtrade.un.org (accessed on 15 October 2020).

4. APS. Common Names of Plant Disease. Available online: https://www.apsnet.org/edcenter/resources/commonnames/Pages/ default.aspx (accessed on 24 October 2020).

5. Mansfield, J.; Genin, S.; Magori, S.; Citovsky, V.; Sriariyanum, M.; Ronald, P.; Dow, M.; Verdier, V.; Beer, S.V.; Machado, M.A. Top 10 plant pathogenic bacteria in molecular plant pathology. Mol. Plant. Pathol. 2012, 13, 614-629. [CrossRef]

6. Jeong, Y.; Kim, J.; Kang, Y.; Lee, S.; Hwang, I. Genetic diversity and distribution of Korean isolates of Ralstonia solanacearum. Plant. Dis. 2007, 91, 1277-1287. [CrossRef] [PubMed]

7. Lee, Y.K.; Kang, H.W. Physiological, biochemical and genetic characteristics of Ralstonia solanacearum strains isolated from pepper plants in Korea. Res. Plant. Dis. 2013, 19, 265-272. [CrossRef]

8. Jiang, G.; Peyraud, R.; Remigi, P.; Guidot, A.; Ding, W.; Genin, S.; Peeters, N. Modeling and experimental determination of infection bottleneck and within-host dynamics of a soil-borne bacterial plant pathogen. bioRxiv 2016. [CrossRef]

9. Jiang, G.; Wei, Z.; Xu, J.; Chen, H.; Zhang, Y.; She, X.; Macho, A.P.; Ding, W.; Liao, B. Bacterial wilt in China: History, current status, and future perspectives. Front. Plant. Sci. 2017, 8, 1549. [CrossRef]

10. Hayward, A. Biology and epidemiology of bacterial wilt caused by Pseudomonas solanacearum. Annu. Rev. Phytopathol. 1991, 29, 65-87. [CrossRef]

11. Guidot, A.; Prior, P.; Schoenfeld, J.; Carrere, S.; Genin, S.; Boucher, C. Genomic structure and phylogeny of the plant pathogen Ralstonia solanacearum inferred from gene distribution analysis. J. Bacteriol. 2007, 189, 377-387. [CrossRef] [PubMed] 
12. Prior, P.; Ailloud, F.; Dalsing, B.L.; Remenant, B.; Sanchez, B.; Allen, C. Genomic and proteomic evidence supporting the division of the plant pathogen Ralstonia solanacearum into three species. BMC Genom. 2016, 17, 90. [CrossRef] [PubMed]

13. Safni, I.; Cleenwerck, I.; De Vos, P.; Fegan, M.; Sly, L.; Kappler, U. Polyphasic taxonomic revision of the Ralstonia solanacearum species complex: Proposal to emend the descriptions of Ralstonia solanacearum and Ralstonia syzygii and reclassify current $R$. syzygii strains as Ralstonia syzygii subsp. syzygii subsp. nov., R. solanacearum phylotype IV strains as Ralstonia syzygii subsp. indonesiensis subsp. nov., banana blood disease bacterium strains as Ralstonia syzygii subsp. celebesensis subsp. nov. and $R$. solanacearum phylotype I and III strains as Ralstonia pseudosolanacearum sp. nov. Int. J. Syst. Evol. Microbiol. 2014, 64, $3087-3103$.

14. Vasse, J.; Frey, P.; Trigalet, A. Microscopic studies of intercellular infection and protoxylem invasion of tomato roots by Pseudomonas solanacearum. Mol. Plant-Microbe Interact. 1995, 8, 241-251. [CrossRef]

15. Hwang, S.M.; Jang, K.S.; Choi, Y.H.; Kim, H.; Choi, G.J. Development of an Efficient Bioassay Method to Evaluate Resistance of Chili Pepper Cultivars to Ralstonia solanacearum. Res. Plant. Dis. 2017, 23, 334-347. [CrossRef]

16. Lee, J.H.; Lee, J.; Oh, D. Resistance of pepper cultivars to Ralstonia solanacearum isolates from major cultivated areas of chili peppers in Korea. Hortic. Sci. Technol. 2018, 36, 569-576.

17. Lee, H.J.; Jo, E.J.; Kim, N.H.; Chae, Y.; Lee, S.W. Disease responses of tomato pure lines against Ralstonia solanacearum strains from Korea and susceptibility at high temperature. Res. Plant. Dis. 2011, 17, 326-333. [CrossRef]

18. Jung, E.J.; Joo, H.J.; Choi, S.Y.; Lee, S.Y.; Jung, Y.H.; Lee, M.H.; Kong, H.G.; Lee, S.W. Resistance evaluation of tomato germplasm against bacterial wilt by Ralstonia solanacearum. Res. Plant. Dis. 2014, 20, 253-258. [CrossRef]

19. Fonseca, N.R.; Oliveira, L.S.; Guimarães, L.M.; Teixeira, R.U.; Lopes, C.A.; Alfenas, A.C. An efficient inoculation method of Ralstonia solanacearum to test wilt resistance in Eucalyptus Spp. Trop. Plant. Pathol. 2016, 41, 42-47. [CrossRef]

20. Kiba, A.; Maimbo, M.; Kanda, A.; Tomiyama, H.; Ohnishi, K.; Hikichi, Y. Isolation and expression analysis of candidate genes related to Ralstonia solanacearum-tobacco interaction. Plant. Biotechnol. 2007, 24, 409-416. [CrossRef]

21. Nakano, M.; Nishihara, M.; Yoshioka, H.; Takahashi, H.; Sawasaki, T.; Ohnishi, K.; Hikichi, Y.; Kiba, A. Suppression of DS1 phosphatidic acid phosphatase confirms resistance to Ralstonia solanacearum in Nicotiana Benthamiana. PLoS ONE 2013, 8, e75124.

22. Huet, G. Breeding for resistances to Ralstonia solanacearum. Front. Plant. Sci. 2014, 5, 715. [CrossRef]

23. Lee, S.M.; Kwak, Y.S.; Lee, K.H.; Kim, H.T. Control efficacy of fungicides on pepper bacterial wilt. Korean J. Pestic. Sci. 2015, 19, 323-328. [CrossRef]

24. Lopes, C.A.; Boiteux, L.S. Biovar-specific and broad-spectrum sources of resistance to bacterial wilt (Ralstonia solanacearum) in Capsicum. Embrapa Hortaliças-Artigo Periódico Indexado (ALICE) 2004, 4, 350-355. [CrossRef]

25. Mimura, Y.; Yoshikawa, M.; Hirai, M. Pepper accession LS2341 is highly resistant to Ralstonia solanacearum strains from Japan. HortScience 2009, 44, 2038-2040. [CrossRef]

26. Tran, N.H.; Kim, B.S. Sources of resistance to bacterial wilt found in Vietnam collections of pepper (Capsicum annuum) and their nuclear fertility restorer genotypes for cytoplasmic male sterility. Plant. Pathol. J. 2012, 28, 418-422. [CrossRef]

27. Matsunaga, H.; Sato, T.; Monma, S. In Inheritance of bacterial wilt resistance in the sweet pepper cv. Mie-Midori. In Proceedings of the 10th Eucarpia Meeting on Genetics and Breeding of Capsicum and Eggplant, Avignon, France, 7-11 September 1998; p. 172.

28. Lafortune, D.; Béramis, M.; Daubèze, A.M.; Boissot, N.; Palloix, A. Partial resistance of pepper to bacterial wilt is oligogenic and stable under tropical conditions. Plant. Dis. 2005, 89, 501-506. [CrossRef] [PubMed]

29. Mimura, Y.; Kageyama, T.; Minamiyama, Y.; Hirai, M. QTL analysis for resistance to Ralstonia solanacearum in Capsicum accession 'LS2341'. J. Jpn. Soc. Hortic. Sci. 2009, 78, 307-313. [CrossRef]

30. Du, H.; Wen, C.; Zhang, X.; Xu, X.; Yang, J.; Chen, B.; Geng, S. Identification of a major QTL ( $q R R s-10.1)$ that confers resistance to Ralstonia solanacearum in pepper (Capsicum annuum) using SLAF-BSA and QTL mapping. Int. J. Mol. Sci. 2019, 20, 5887. [CrossRef]

31. Lebeau, A.; Daunay, M.C.; Frary, A.; Palloix, A.; Wang, J.F.; Dintinger, J.; Chiroleu, F.; Wicker, E.; Prior, P. Bacterial wilt resistance in tomato, pepper, and eggplant: Genetic resources respond to diverse strains in the Ralstonia solanacearum species complex. Phytopathology 2011, 101, 154-165. [CrossRef]

32. Kim, B.; Cheung, J.; Cha, Y.; Hwang, H. Resistance to bacterial wilt of introduced peppers. Korean J. Plant Pathol. 1998, 14, 217-219.

33. Huh, S.U.; Kim, K.J.; Paek, K.H. Capsicum annuum basic transcription factor 3 (CaBtf3) regulates transcription of pathogenesisrelated genes during hypersensitive response upon Tobacco mosaic virus infection. Biochem. Biophys. Res. Commun. 2012, 417, 910-917. [CrossRef]

34. Yeom, S.I.; Baek, H.K.; Oh, S.K.; Kang, W.H.; Lee, S.J.; Lee, J.M.; Seo, E.; Rose, J.K.; Kim, B.D.; Choi, D. Use of a secretion trap screen in pepper following Phytophthora capsici infection reveals novel functions of secreted plant proteins in modulating cell death. Mol. Plant-Microbe Interact. 2011, 24, 671-684. [CrossRef] [PubMed]

35. Hamada, H.; Takeuchi, S.; Kiba, A.; Tsuda, S.; Suzuki, K.; Hikichi, Y.; Okuno, T. Timing and extent of hypersensitive response are critical to restrict local and systemic spread of Pepper mild mottle virus in pepper containing the L3 gene. J. Gen. Plant. Pathol. 2005, 71, 90-94. [CrossRef]

36. Yang, J.W.; Yu, S.H.; Ryu, C.M. Priming of defense-related genes confers root-colonizing bacilli-elicited induced systemic resistance in pepper. Plant. Pathol. J. 2009, 25, 389-399. [CrossRef]

37. Kim, B.; Hwang, I.S.; Lee, H.J.; Lee, J.M.; Seo, E.; Choi, D.; Oh, C.S. Identification of a molecular marker tightly linked to bacterial wilt resistance in tomato by genome-wide SNP analysis. Theor. Appl. Genet. 2018, 131, 1017-1030. [CrossRef]

38. Lee, J.H.; Jang, K.S.; Choi, Y.H.; Kim, J.C.; Choi, G.J. Development of an efficient screening system for resistance of tomato cultivars to Ralstonia solanacearum. Res. Plant. Dis. 2015, 21, 290-296. [CrossRef] 
39. Bocsanczy, A.M.; Achenbach, U.C.; Mangravita, N.A.; Yuen, J.M.; Norman, D.J. Comparative effect of low temperature on virulence and twitching motility of Ralstonia solanacearum strains present in Florida. Phytopathology 2012, 102, 185-194. [CrossRef] [PubMed]

40. Deslandes, L.; Pileur, F.; Liaubet, L.; Camut, S.; Can, C.; Williams, K.; Holub, E.; Beynon, J.; Arlat, M.; Marco, Y. Genetic characterization of RRS1, a recessive locus in Arabidopsis thaliana that confers resistance to the bacterial soilborne pathogen Ralstonia solanacearum. Mol. Plant-Microbe Interact. 1998, 11, 659-667. [CrossRef] [PubMed]

41. Aoun, N.; Tauleigne, L.; Lonjon, F.; Deslandes, L.; Vailleau, F.; Roux, F.; Berthomé, R. Quantitative disease resistance under elevated temperature: Genetic basis of new resistance mechanisms to Ralstonia solanacearum. Front. Plant. Sci. 2017, 8, 1387. [CrossRef] [PubMed]

42. Lebeau, A.; Gouy, M.; Daunay, M.C.; Wicker, E.; Chiroleu, F.; Prior, P.; Frary, A.; Dintinger, J. Genetic mapping of a major dominant gene for resistance to Ralstonia solanacearum in eggplant. Theor. Appl. Genet. 2013, 126, 143-158. [CrossRef]

43. Cruz, A.P.Z.; Ferreira, V.; Pianzzola, M.J.; Siri, M.I.; Coll, N.S.; Valls, M. A novel, sensitive method to evaluate potato germplasm for bacterial wilt resistance using a luminescent Ralstonia solanacearum reporter strain. Mol. Plant-Microbe Interact. 2014, 27, 277-285. [CrossRef] [PubMed]

44. Wang, K.; Remigi, P.; Anisimova, M.; Lonjon, F.; Kars, I.; Kajava, A.; Li, C.H.; Cheng, C.P.; Vailleau, F.; Genin, S. Functional assignment to positively selected sites in the core type III effector RipG7 from Ralstonia solanacearum. Mol. Plant. Pathol. 2016, 17, 553-564. [CrossRef] [PubMed]

45. Pontier, D.; Godiard, L.; Marco, Y.; Roby, D. Hsr203J, a tobacco gene whose activation is rapid, highly localized and specific for incompatible plant/pathogen interactions. Plant. J. 1994, 5, 507-521. [CrossRef]

46. Planas-Marquès, M.; Bernardo, F.M.; Paulus, J.; Kaschani, F.; Kaiser, M.; Valls, M.; Van der Hoorn, R.A.; Coll, N.S. Protease activities triggered by Ralstonia solanacearum infection in susceptible and tolerant tomato lines. Mol. Cell. Proteom. 2018, 17, 1112-1125. [CrossRef] [PubMed]

47. Janse, J.; Van den Beld, H.; Elphinstone, J.; Simpkins, S.; Tjou-Tam-Sin, N.; Van Vaerenbergh, J. Introduction to Europe of Ralstonia solanacearum biovar 2, race 3 in Pelargonium zonale cuttings. J. Plant. Pathol. 2004, 86, 147-155.

48. Singh, D.; Yadav, D.; Sinha, S.; Choudhary, G. Effect of temperature, cultivars, injury of root and inoculums load of Ralstonia solanacearum to cause bacterial wilt of tomato. Arch. Phytopathol. Plant. Prot. 2014, 47, 1574-1583. [CrossRef]

49. Caranta, C.; Palloix, A. Both common and specific genetic factors are involved in polygenic resistance of pepper to several potyviruses. Theor. Appl. Genet. 1996, 92, 15-20. [CrossRef]

50. Thabuis, A.; Palloix, A.; Pflieger, S.; Daubeze, A.M.; Caranta, C.; Lefebvre, V. Comparative mapping of Phytophthora resistance loci in pepper germplasm: Evidence for conserved resistance loci across Solanaceae and for a large genetic diversity. Theor. Appl. Genet. 2003, 106, 1473-1485. [CrossRef] [PubMed]

51. Tran, N.H.; Kim, B.S. Inheritance of resistance to bacterial wilt (Ralstonia solanacearum) in pepper (Capsicum annuum L.). Hortic. Environ. Biotechnol. 2010, 51, 431-439.

52. Yi, S.Y.; Lee, D.J.; Yeom, S.I.; Yoon, J.; Kim, Y.H.; Kwon, S.Y.; Choi, D. A novel pepper (Capsicum annuum) receptor-like kinase functions as a negative regulator of plant cell death via accumulation of superoxide anions. New Phytol. 2010, 185, 701-715. [CrossRef] [PubMed]

53. Simko, I.; Piepho, H.P. The area under the disease progress stairs: Calculation, advantage, and application. Phytopathology 2012, 102, 381-389. [CrossRef] [PubMed]

54. Kang, W.H.; Sim, Y.M.; Koo, N.; Nam, J.Y.; Lee, J.; Kim, N.; Jang, H.; Kim, Y.M.; Yeom, S.I. Transcriptome profiling of abiotic responses to heat, cold, salt, and osmotic stress of Capsicum annuum L. Sci. Data. 2020, 7, 1-7. [CrossRef] 